\title{
MEGISMERÉS KÍSÉRLETEKEN KERESZTÜL - EGY ÉLMÉNYPEDAGÓGIAI MÓDSZER BEMUTATÁSA
}

\author{
Majár János \\ egyetemi docens, Miskolci Egyetem, Fizikai és Elektrotechnikai Intézet, Fizikai Tanszék \\ 3515 Miskolc, Miskolc-Egyetemváros, e-mail: fizmajar@uni-miskolc.hu
}

\begin{abstract}
Absztrakt
A fizika, és általában a természettudományok oktatásában egyre fontosabb a tudományos megismerés alapelveinek és módszertanának átadása. Emellett egyre nagyobb teret nyernek az interaktív, vagy élménypedagógiai módszerek. A jelen cikk egy ilyen módszert, és annak tapasztalatait mutatja be. A módszer során a résztvevök kiscsoportos munka keretében, kísérleteken keresztül tárnak fel egy jelenséget, vagy egy technikai eszköz müködését. A módszerrel kapcsolatos tapasztalatok egyetemi tanórákon, illetve középiskolás diákoknak szervezett külön alkalmakon születtek. Az alábbiakban egy pillanatfelvétel kerül bemutatásra a módszer jelenlegi állapotáról, tartalmazva annak fejlesztési lehetőségeit is.
\end{abstract}

Kulcsszavak: pedagógia, élménypedagógia, kísérletek, természettudományos megismerés

\begin{abstract}
In the teaching of physics, and of the natural sciences in general, it is becoming increasingly important to impart the basic principles and methodology of scientific exploration. In addition, interactive or experiential pedagogical methods are increasingly gaining ground. This article presents such a method and the related experiences. During the method, the participants explore a phenomenon or the operation of a technical device through small group work, performing experiments. The experiences related to the method were gained in university classes and during special events organized for high school students. In the following a snapshot of the current state of the method is presented, including its development opportunities.
\end{abstract}

Keywords: pedagogy, experiential pedagogy, experiments, exploration of natural sciences

\section{Bevezetés}

A természettudományos és mérnöki képzésben egyre nagyobb szerepet kapnak (kellene kapjanak) a megismerés általános módszerei. A tudományok és a technikai környezetünk fejlödése olyan diverzitást hozott, amely miatt a diákok és hallgatók képzésében egyre többet kell foglalkozni a tudományok általános müködésének bemutatásával, hiszen minden releváns jelenség bemutatása ma már nem realitás. A mérések és mérhető mennyiségek világának megismerése, a modellezés módszereinek sikeres alkalmazása, a természettudományos megismerés és módszertan korlátainak [1] helyes ismerete mind olyan tudások és készségek/képességek, amelyek egyre nagyobb szerepet játszanak az oktatás/képzés sikerességében (vagy éppen sikertelenségében). Továbbá, ez meghatározza, hogy mennyire lesznek jó szakemberek azok a fiatalok, akik természettudományos (vagy általánosabban tudományos), vagy mérnöki pályára lépnek. 
Egyetemi oktatói munkám során a kezdetektől igyekeztem ezeket az elveket, módszereket bemutatni az óráimon, általában a tananyag részleteiben elrejtve. Azonban érzékeltem, hogy szükség lenne egy kézzelfoghatóbb, interaktívabb módszerre is.

Általánosságban is elmondható, hogy növekszik a fontossága azoknak a módszereknek, amelyek a frontális oktatási folyamatokat kiegészítik készség- és képességfejlesztéssel, interaktív módszerekkel. Ezek közül a természettudományos oktatásban megnövekedett az élménypedagógiai módszerek használatának szükségessége [2].

A felnövő új generációk életét egyre inkább eluralja a számítástechnikai eszközök világa, amely egyik oldalról rengeteg információt tesz elérhetővé, másrészt az élmények átélésétől veszi el az időt [3]. Jellemzővé vált az egyetemi hallgatók körében, hogy egyszerủ mechanikai rendszerek müködését már nem élték meg (például sokan nem igazán libikókáztak) gyerekkorukban. Ezek a „tapasztalások” hiányként jelennek meg az oktatásban, ahol az alkalmazott módszertanok építenek ezekre a tapasztalatokra [4].

Ezen kihívásokra válaszul 2015-től az alapozó Fizika tárgyak oktatásába - ha a tananyaggal megfelelö ütemben haladtunk - bevezettem évfolyamonként egy-egy alkalommal a bemutatandó élménypedagógiai módszert, amelyen alkalmanként 15-30 fö vett részt. Ennek lényege, hogy a résztvevők ismerjenek meg egy egyszerú jelenséget, méghozzá általuk kitalált, megtervezett kísérleteken keresztül, kiscsoportos munka keretében. A feladat tárgya lehet egy ellentmondásosnak tünő jelenség, egy egyszerü technikai eszköz müködése, vagy egy kísérlet kritikus paramétereinek megismerése.

A módszer során bármilyen eszköz használható, egyedül az internet nem - egy megoldatlan kérdés kutatásakor mérnökként hiába keresik a megoldást a neten. Ez egyrészt azért volt fontos, mert maguk a feladatok elég egyszerüek (mindennel együtt egy maximum kétszer 50 perces tanórába bele kellett férjen a folyamat, így bonyolult jelenségek nem vállalhatóak), másrészt a módszer fontos része annak megtapasztalása, hogy a kutatómunkában a választ „nem kapjuk ingyen”.

Ezen felül a módszer része annak a helyzetnek a szimulálása, amikor egy kutatónak (kutatócsoportnak) pályáznia kell egy nagyobb mérőmüszer bérlésére. A mérnök hallgatók jó része számára ez aligha elkerülhető. Ezt megfelelő segédanyagokkal, némileg játékosan igyekeztem megvalósítani.

2018-ban a Miskolci Egyetem „Tudás-Vár a Miskolci Egyetem” projektjének keretében alkalmam volt a módszerről részletes leírást készíteni [5], illetve támogatva volt négy alkalom, amelyen középiskolások vettek részt, és ezek kényelmesebb, egyenként négy órás időkeretben valósultak meg. Ebből két alkalommal a miskolci Herman Ottó Gimnázium (a 2018-as alkalommal 9 fö, 2019-ben 17 fö), két alkalommal a szintén miskolci Bláthy Ottó Villamosipari Szakgimnázium (2018-ban 15 fö, 2019-ben 17 fö) diákjait láttam vendégül. Mindegyik alkalommal a Miskolci Egyetem Gépészmérnöki és Informatikai Kara Fizikai Intézetének infrastruktúrája biztosította a kereteket [6]. Ezen négy alkalom legfontosabb tapasztalatait rövid tanulmányban foglaltam össze [7].

A jelen cikk célja ennek az élménypedagógiai módszernek a rövid bemutatása, illetve a legfontosabb tapasztalatok összegzése, immáron nem csak a középiskolai diákok, hanem az egyetemisták részvételével létrejött alkalmakra is támaszkodva. Így átfogóbb képet igyekszem adni a módszer müködéséről, és tovább kutatom annak fejlesztési irányait.

\section{A módszer leírása}

A módszer lényege röviden megfogalmazva az, hogy a résztvevők kiscsoportokban, tudatosan tervezett kísérlet-sorozaton keresztül feltárják egy ellentmondásosnak tünő jelenség hátterét, vagy megismerik egy általuk nem ismert gép müködésének alapelvét, esetleg felmérik egy jelenség föbb paramétereit, meghatározva azok hatását. 
Ehhez segédanyagokat kapnak, amelyek segítenek a folyamat és az egyes kísérletek tervezésében, illetve az eredmények dokumentálásában. Ezen felül biztosítottak bizonyos kísérleti eszközök, amelyek segítségével elvégezhetik saját kísérleteiket.

Kiemelendő része még a módszernek, hogy annak vezetője minden kísérlet végrehajtására a neki leadott tervek alapján ad engedélyt, miközben figyelemmel kíséri az egyes csoportok munkáját és előrehaladását.

A megvalósulás tekintetében külön foglalkozni fogunk az egyetemi gyakorlatokon (kétszer 50 perces időtartam) és a középiskolásoknak szervezett külön foglalkozásokon (alkalmanként 4 óra időtartam) lebonyolított alkalmakkal.

\subsection{Célkitűzések, a módszer fejlesztő hatásának fő irányai}

\subsubsection{Megismerés kísérletezéssel}

A módszer egyik fö célkitüzése, hogy a résztvevők betekintést nyerhessenek a természeti (és mérnöki) folyamatok kísérleteken keresztül történő megismerésébe.

Ennek fontosságát aligha lehet túlbecsülni. A megismerési/kutatási tevékenységek során kiemelten fontos, hogy a kutató tisztában legyen azzal, hogy pontosan milyen alapelvek szerint, milyen módszerekkel történik a jelenségek megismerése. A mérnökök számára fontosabb az induktív eljárásmód, még akkor is, ha az a jelenkor tudományos tevékenységében gyakran keveredik a deduktív úttal.

Ebbe az induktív gondolkodásmódba ad gyakorlatorientált betekintést a módszer.

Fontos kiemelni még, hogy a módszer aktív tevékenységen keresztül teszi lehetővé a megismerést, a jelenkor fiatal generációi ezekre nyitottabbak, mint a nagyobb elmélyülést igénylő elméletibb, esetleg deduktív megismerési módokra.

A módszer alkalmazásával a résztvevők nem csak kipróbálják a kísérletezést és az induktív kutatási módszert, hanem találkozhatnak több olyan elvi és gyakorlati problémával, ami jellemző a természettudományos/mérnöki kutatásokra. Így saját bőrükön tapasztalhatják meg, mennyire sok mindenen múlik a megismerési folyamat sikere, és hogy nem mindig egyszerü addig ismeretlen jelenségekröl megalapozottan biztosat állítani.

Ennek során kapnak egy érzékenyítést is azzal kapcsolatban, hogy saját véleményük (szakvéleményük) kialakítása során fontos megfigyelhető jelenségekre, mérhető (mért) mennyiségekre alapozni, és hogy ezeknek a (szak)véleményeknek tükröznie kell a megismerési folyamat nehézségeit és bizonytalanságát is - miközben igyekeznek kutatóként a bizonytalanságot és a pontatlanságot minimálisra csökkenteni.

\subsubsection{Tervezés}

További kiemelt cél, hogy a résztvevők tervszerüen igyekezzenek a kísérleteket végrehajtani, tudatosan végig-gondolva a megismerési folyamatot, illetve egyenként is megtervezve a kísérleteket [4].

Ez egyrészt azért fontos, mert a 21. század rohanó világában a rengeteg készen kapott „,forgatókönyv" helyett egy kutatónak sajátos megközelítéssel, saját menetrendet követve kell terveznie a kutatótevékenységét (természetesen építve a korábbi tapasztalatokra, standardokra). Ehhez nagyon kevés szakmódszertani tudást, és személyiségükre szabott kapaszkodót kapnak a felnövekvő generációk [3].

A módszer alkalmazása során saját utat, saját menetrendeket kell kialakítaniuk, amelyekkel sikeresek tudnak lenni a kutatásaik során.

A tervezés kapcsán a másik motivációt a nagy méröberendezések/mérörendszerek müködése adja. Sok mérnöknek és természettudományban érintett kutatónak van időről időre szüksége olyan mérőberendezés használatára, amelyhez csak nagy cégeken, kollaborációkon, méröhelyeken keresztül fér 
hozzá. Ezekben az esetekben kiemelten fontos, hogy precízen tervezve legyen a kísérlet, amihez a berendezést „bérlik”, vagy pályáznak rá, és ennek része az is, hogy helyesen kell kommunikálniuk munkájukat és kutatási igényeiket, ennek részeként láthatóvá kell tenniük, hogy az elvégezni kívánt kísérlet milyen kutatásba és hogyan illeszkedik, jelezve annak relevanciáját is.

\subsubsection{Dokumentálás}

A módszer szempontjából kevésbé hangsúlyos, de a kutatási tevékenységben aligha túlbecsülhető a dokumentálás kérdése. Lévén a tervezett kutatási folyamatot a résztvevők a végrehajtott eredmények fényében újra és újra felülvizsgálják, komoly szerepe van az eredményeik megfelelő dokumentálásának. Azonban mégsem ez a módszer hangsúlyos eleme, amellett, hogy a tervezési segédanyagok segítenek az adatok megfelelö feljegyzésében is.

\subsubsection{Ideális helyzet és realitás}

A fenti célok megvalósítására a bemutatandó módszer csak korlátozottan alkalmas, főként a rövid idő és a kis ismétlésszám miatt. Aligha várható el, hogy a résztvevők azonnal teljes értékủ kutatási tervet készítsenek, megfelelően előkészítsenek minden kísérletet, majd korrekten le is dokumentálják az eredményeket. Mindaz, ami a módszer bemutatásánál leírásra kerül, alapvetően egy ideális (cél)állapotot tükröz.

Valójában a résztvevők csupán bele-belekóstolnak ezekbe, és akik egynél többször vesznek részt ilyen alkalmon, azok legalább viszonyba kerül(het)nek a megismerés nehézségeivel, vagy a kutatásmódszertan néhány szárazabb elemével. De az időkerettől függetlenül sem érdemes a fenti célok elérését túlerőltetni, mivel fontos a játékosság, a minél színesebb megtapasztalása ezeknek a kihívásoknak, és persze kiemelten fontos, hogy sikerélményekkel és ráébredésekkel gazdagodjanak a résztvevők.

A tapasztalatok összefoglalásakor külön kitérek arra, hogy a módszer mely elemei müködtek jól, és melyeknél kellett kompromisszumokat kötni, esetleg némelyiket elhagyni.

\subsubsection{Csoportmunka}

A fenti célokon kívül fontos még kiemelni, hogy a módszer - megfelelő vezetéssel - sok oldalról, és nagyon hatékonyan fejleszti a csoportmunka végzéséhez szükséges készségeket, illetve az önismeretet. Ugyanis ha a vezető (általában oktató, vagy pedagógus) csak segíti a csoportok munkáját, és a müködésükbe és ötleteikbe nem „szól bele” (ez lenne a kívánatos hozzáállás), akkor természetes módon rendeződik el a csoporton belül a szereposztás. Több alkalom után pedig ezek a mindennapokból „hozott" szerepek is átrendeződhetnek a (csoportmunka szempontjából) valós képességeknek és igényeknek megfelelöen.

\subsection{Tartalmi elemek}

Munkám során az alábbi feladatokat dolgoztam ki és adtam ki diákoknak, hallgatóknak (ez ügyben inspirációul szolgált $[8,9])$.

\subsubsection{Kiskocsik ütközése}

Egyszerü sínen mozgó kiskocsikat ütköztetve alacsony sebesség mellett érdekes „ellentmondás” alakul ki. A két kiskocsit egyik irányba ütköztetve úgy viselkednek, mintha egyenlő lenne a tömegük, megfordított szereposztás esetén pedig olyan az ütközés dinamikája, mintha a tömegek különböznének.

A tömegek egyébként különböznek, az egyik kiskocsi a rugós ütköző miatt nagyobb tömegü. A látszólagos ellentmondás oka az, hogy a két esetben a tengelynél ébredő súrlódási erők más minőségüek. 
Mivel a kisebb tömegű kiskocsi visszapattan az ütközés során, egy pillanatra megáll, és a tengelynél ébredő súrlódási erő tapadási súrlódás lesz. Kis sebességek esetén nem is indul el visszafelé, így az ütközés első ránézésre olyan dinamikájú, mint az egyenlő tömegủ esetben.

A másik szereposztással végrehajtott kísérletnél a nagyobb tömegü kiskocsi az ütközés után - bár kisebb sebességgel - az eredeti irányba halad, a fenti effektus nem lép fel.

A kísérletről és a jelenség magyarázatáról (és a kizárható okokról) külön segédanyag készült.

\subsubsection{Euler korong}

Euler korong precesszáló forgó mozgását figyeljük meg egy sík, majd egy homorú felületen. Az utóbbi esetben sokkal tovább mozog a korong, sokkal több periódus után áll csak meg.

A jelenség magyarázata - amit a résztvevők keresnek - abban rejlik, hogy sík felületen a korong precesszáló forgását a sík felület és a korong felülete közötti súrlódási erő biztosítja, ami viszont nagy vesztességgel jár, a korong rövid időn belül megáll. Homorú felületen a „pályán tartás” nagy mértékben a felület által kifejtett tartóeröre hárul, sokkal kisebb szerep jut a súrlódásnak. Így sokkal kisebb a veszteség, a forgó mozgás tovább tart.

Ehhez a kísérlethez is készült fényképekkel megtámogatott segédanyag.

\subsubsection{Egyenáramú motor}

Másfajta kihívást hordoz az egyszerü egyenáramú motor. Itt nem egy jelenséget kell megmagyarázni, hanem a motor müködésének alapelveit feltárni. Ez egy egyszerü megvalósítása az angol szaknyelvben ,reverse engineering” módszernek [10].

A motor a legegyszerübb egyenáramú motor, ahol a kefe kialakításának köszönhetően a forgó tekercs mágneses terének polaritása a forgás félperiódusában újra és újra változik. Ez külső mágneses térbe helyezve létrehozza a forgáshoz szükséges forgatónyomatékot.

Érdekes kihívás lehet ennél a feladatnál - ha már a motor működésének az alapját megismerték - a meghatározó paraméterek feltárása, illetve a motor továbbfejlesztéséhez (kísérletekkel visszaigazolt) ötletek gyüjtése is.

A motor összeállításáról és a feladatokról itt is segédanyag készült.

\subsubsection{Lufi viselkedése alacsony nyomáson}

A nyomás fogalmának oktatásakor kiderül, hogy annak kapcsán több rossz beidegződés is jelen van a tanulóknál. Ezért fontos a vákuumszivattyús kísérletek bemutatása, értelmezése.

A fenti módszert a lufi esetében lehet sikeresen alkalmazni, egyszerüsége miatt ez egy jó „belépő” feladat. A vákuumszivattyúval légtelenített búra alatt a kevés levegöt tartalmazó lufi a nyomáskülönbség ellenére sem tölti ki a rendelkezésre álló teret.

A jelenség magyarázata nagyon egyszerü, a lufi anyagának is van a rugalmasságából származó nyomás-komponense. A magyarázat megtalálásánál azonban érdekesebb feltárni, hogy milyen paraméterek befolyásolják (és hogyan) az egyensúlyi helyzetet.

\subsubsection{Forralás (fagyasztás) szobahömérsékleten}

A vákuumszivattyúval végzett kísérletek között már komolyabb a víz forralása alacsony nyomáson, szobahőmérsékleten. Akik ennek okát nem tanulták, azok valószínüleg nem fogják megtalálni a helyes választ, mivel a jelenség megértéséhez ismerni kell a forrás folyamatát, és aki azt ismeri, az a forrás kialakulásának nyomás-függéséről is tanult.

Ezen kísérletek esetében a jellemző paraméterek feltárása lehet érdekes feladat.

A kísérlet nehezített változata az, amikor 0 Celsius fokos vizet kezdünk alacsony nyomáson forralni, ami ennek hatására megfagy (a forrás közben a víz hőt veszít, és ennek hatására jég képződik, ad- 
dig, amíg egy összefüggő jégréteg létre nem jön, mivel az ellehetetleníti a forrást). Ennek végrehajtása csak szük időkeretben sikerül, és komoly előkészületeket igényel. Viszont itt a jelenség ellenőrzése, megértése is komoly kihívást jelentő feladat.

\subsection{6. Új feladatok kitalálása}

Azok számára, akik többször is részt vettek a módszer alkalmain, komoly kihívás lehet hasonló feladatok kitalálása és előkészítése. Erre sajnos még nem került sor, nem volt olyan csoport, aki elég alkalommal részt vett volna ahhoz, hogy alkotó módon tudjon hozzájárulni a fejlesztéshez. Mégis érdemes itt megjegyezni ezt a lehetőséget, hiszen ez egészen más szinten fejleszti a kutatótevékenységhez kapcsolódó készségeket, mint a kiinduló módszer önmagában.

\subsection{A módszer megvalósulása különböző keretekben}

A módszer két, különböző keretrendszerben került megvalósításra. Az egyik egyetemi hallgatókkal, a tanórák keretében, alkalmanként kétszer 50 perces gyakorlat időtartamában. A másik középiskolásoknak szervezett külön alkalmakon, amelyeknek az időtartama 4 óra körül mozgott (az eredeti módszertani anyagban [5] egész napos alkalmak kerültek kidolgozásra, de már az első alkalommal sem volt realitása ekkora időkeretben megvalósítani).

A két különböző esetből érdemes az előbbi menetrendjét leírni (annak időkerete az a minimális idő, ami egy-egy feladat végrehajtásához szükséges), az utóbbi esetében ez kerül kiegészítésre. Érdemes megjegyezni, hogy a módszertani anyagban ezen lépések részletezve vannak, javasolt időkeretekkel, jellemző problémaforrások feltárásával).

\subsubsection{Megvalósitás egyetemi gyakorlati óra keretében}

Egy gyakorlati óra esetében egy feladat elvégzése az alábbi lépésekből áll.

A módszer vezetője részletezi az óra menetrendjét és a feladatmegoldás lényegi lépéseit. A résztvevők kialakítják a kiscsoportokat, amelyek 3-4 fővel tudnak hatékonyan müködni.

Ezután az oktató bemutatja a megvizsgálandó eszközt, vagy a feltárandó jelenséget. Röviden felvezeti a kérdéses pontokat, tisztázva, hogy mi a feladat.

Ezek után a résztvevők a csoportokban röviden megbeszélik, milyen elöismeretekkel rendelkeznek, és mit gondolnak a jelenség (gép müködésének) magyarázatáról. Ennek mentén elkészítik a „kutatási tervet", vagyis tisztázzák, hogy milyen kísérleteken keresztül szeretnék megvizsgálni a történteket.

A kidolgozott folyamat-tervet követve megtervezik az első kísérletet. A tervet benyújtják az oktatónak, aki elbírálja azt. Ha megfelelő, a résztvevők elvégezhetik a kísérletet. Ha nem, javaslatot tesz a hiányosságok/hibák kezelésére.

A résztvevők végül elvégzik a kísérletet, és felírják az eredményeket, megbeszélik a következtetéseiket, esetleg újra-tervezik a korábban kitalált kísérleteket. Abban az esetben, ha a rendelkezésre álló eszközökkel a kísérlet nem végrehajtható, az oktató vállalhatja, hogy elmeséli, mi lenne a kísérlet kimenetele, ha elvégeznék. Ez azonban kerülendő, és nagy körültekintést igényel.

Az utóbbi két lépést ismétlik a kiscsoportok a rendelkezésre álló időkeretben. Ha egy csoport nagyon hamar megtalálja a helyes választ, akkor kaphatnak plusz feladatokat a 2.2. alfejezetben leírtak szerint.

A csoportmunkára szánt időkeret lejártával az oktató ismerteti a feladat megoldását, majd értékeli a csoportok munkáját. Ennek kiemelten fontos része azon jellegzetes hibák pozitív attitüdű bemutatása, amelyek általánosan jellemzőek a módszer alkalmazásakor. Továbbá kiemelendő, hogy az értékelés során nem az a kiemelt szempont, hogy a csoport megtalálta-e a keresett választ, fontosabb szempont, hogy volt-e épkézláb elképzelésük, tudták-e az elgondolásaikat igazolni, a kísérleteket tervezetten 
végrehajtani, kiértékelni. A résztvevői körtől függően az is firtatható, hogy a csoportok hogyan müködtek.

Tanórai keretben az értékelés része a csoporton belül szétosztható plusz pontok odaítélése.

\subsubsection{Megvalósítás külön alkalmon}

Abban az esetben, amikor középiskolások érkeztek külön szervezett alkalmakra (egyenként 4 órás időkeretben), a fenti módszert ki lehetett, és ki kellett egészíteni további elemekkel.

Az új kihívás ebben az esetben az, hogy a résztvevők nem ismerik a módszer vezetőjét, így külön figyelmet kellett szentelni a megismerkedésnek, és a megfelelő „komfort”-érzet kialakításának. A másik oldalról viszont a rendelkezésre álló időkeret legalább duplája a tanórai keretben lebonyolított esetének.

Ebben az esetben a módszer kölcsönös bemutatkozással, és egy nyitó előadással kezdődik, amelyben az oktató a frontális oktatási módszerből vezeti át a csapatot az élménypedagógiai szakaszba. Ez az előadásanyag a természettudományos megismerés néhány fogalmát és módszerét tisztázza, majd röviden bemutatja a módszert. Az előadáshoz powerpoint-os bemutató-anyag készült.

Ezen túl általánosságban elmondható, hogy mindenre érdemesebb több időt szánni, és több plusz feladat adható ki ebben az esetben. Sőt, érdemes több feladat között választási lehetőséget biztosítani.

Fontos megjegyezni, hogy a módszer eredeti terveiben egész napos folyamat szerepel, ez azonban a szervezés tekintetében sem volt realitás, másrészt a résztvevők sem töltötték volna ki az időkeretet. Ez utóbbi onnan tudható, hogy a négy órás időkeret kitöltése is nehézségekbe ütközött, erről a tapasztalatoknál lesz szó bővebben.

Külön odafigyelést igényel ebben az esetben a szünetek kezelése. Alapvetően a csoportok maguk döntenek a saját szüneteik megtartásáról, de érdemes figyelni a túl sok, vagy túl kevés időt szüneten töltő csoportokkal. Ezen túl, a tapasztalat azt mutatja, hogy érdemes beiktatni egy közös, nagyobb időtartamú szünetet félidő környékén.

\subsubsection{A tervezéshez kiadott segédanyagok tartalma}

Ebben az alfejezetben röviden szerepeltetem a megismerési folyamat és a kísérletek tervezéséhez és értékeléséhez készített anyagok tartalmát. Ezek szerkesztett változatai három, illetve két oldal hosszúak, ezeket a résztvevők nyomtatva kapják kézhez, és ezeken dolgozhatják ki a kísérleteiket.

A kísérletsorozat tervezéséhez kiadott anyag kérdései:

- Kísérlet-sorozat tervezése

-Csoport információk

- Csoport neve

- Csoport tagjai

- Intézmény, osztály/évfolyam

-Feladat információk

- Választott feladat

- A feladat rövid leírása

- Felhasználható eszközök listája

-Ötletelés

- Írjátok össze, hogy milyen gondolataitok, ötleteitek vannak a feladat megoldására!

- Tanácsok (az ehhez a szakaszhoz adott tanácsok szerepelnek ebben a sorban)

-Főbb kérdések

- Melyek azok a kérdések, amelyeket a válasz megtalálásához a leginkább tisztázni kellene? 
- Ezeket milyen sorrendben lehet/érdemes megválaszolni?

- Tanácsok (az ehhez a szakaszhoz adott tanácsok szerepelnek ebben a sorban) -A Terv

- Milyen kísérletek végrehajtása során válaszolnátok meg a fenti kérdéseket?

- Ezeket a kísérleteket milyen sorrendben hajtanátok végre?

- Tanácsok (az ehhez a szakaszhoz adott tanácsok szerepelnek ebben a sorban)

- Kísérlet-sorozat nyomon követése (kísérletenként kitöltendő, egy oldalra kétszer fér fel)

-Kísérlet eredményei

- Mi lett a kísérlet kimenete, eredménye?

- Milyen kérdésre kaptatok választ, és mit?

- Az eredmények hogyan befolyásolják a tervezett kísérlet-sorozatot?

- Ha változtatni kell a kísérletsorozat menetrendjén, azt itt megtehetitek.

Az egyes kísérletek tervezéséhez kiadott anyag kérdései (az oktató a kísérleti tervek elbírálásánál csak ezt az anyagot látja):

- Kísérlet tervezése

-Alapinformációk

- Csoport neve

- Választott feladat

- Hányadik kísérlet?

-Kísérlet információk

- A kísérlet célja, helye a tervezett folyamatban

- A kísérlet végrehajtásának leírása (röviden!)

- Felhasználandó eszközök listája

- Tervezett időkeret

- Speciális kérések

-Elbírálás (A vezető az alábbi elemeket választhatja)

- Engedélyezem! (A vezető tölti ki!)

- Ezeket a javításokat, kiegészítéseket kérem! (A vezető tölti ki)

-(A most következő három szakaszból a csoportnak választania kell egyet, és az arra vonatkozó részeket kidolgozni a kísérlet előtt és után)

-Konkrét elképzelés van

- Milyen eredményt vártok a kísérlettől?

- A kísérlet visszaigazolta az elképzeléseiteket? Ha nem, miben nem?

-Több variáció lehetséges

- Milyen lehetséges eredményeket tudtok elképzelni?

- A kísérlet melyik variációt igazolta vissza? Ha egyiket sem, mi lett az eredmény?

-Elgondolásunk sincs, mi fog történni

- Mi lett a kísérlet eredménye? Milyen válaszokat találtatok?

Ez így természetesen túl-formalizált lenne. Ezért nem elvárás, hogy ezeket az anyagokat a résztvevők pontosan, teljes részletességgel kitöltsék, az a kísérletezés játékosságát is csökkentené. Ezek csupán segédanyagok. A lényeg, hogy ezekre többször ránézzenek, foglalkozzanak, ismerkedjenek vele. Egy aktív csoport esetén észrevehető, hogy a kísérletek tervei a folyamat során egyre inkább megfelelnek ezeknek a segédanyagoknak akkor is, ha külön lapon tervezik azokat. 


\section{Tapasztalatok}

Általánosan elmondható, hogy az ezen feladatokkal töltött egyetemi tanórák, illetve a külön alkalmak is mind jól sikerültek. A tanórák esetében voltak, akik unatkoztak, vagy nem vették komolyan a feladatot, de a többiek - saját bevallásuk szerint - sokat tanultak ezekből, és alapvetően jól érezték magukat az egyébként több szempontból is stresszes helyzetben. Általános volt a meggyőződés, hogy „több kellene ebböl”.

A jelen fejezetben igyekszem tematikusan rendezve kitérni azokra az általános tapasztalatokra, amiket a leginkább meghatározónak találtam.

Van azonban egy jelenség, amelyre még itt, az elején szeretnék kitérni, mivel az a módszer egészét, és annak majdnem minden aspektusát érinti.

A résztvevők mindegyik alkalommal - függetlenül a megvalósulás módjától, kereteitől - zavarba jöttek a módszerben együttesen megvalósuló szabadságtól és kötöttségtől. Azt, hogy a csoportok néhány segédanyag mentén, de lényegében saját maguk dolgoztak, saját menetrendek és szabályok szerint, nem tudták összeegyeztetni azzal a kötöttséggel, amit a kísérletek tervezése és a tervek elbírálása, vagy a kiscsoportos müködés jelentett.

Éppen ezért igyekeztek vagy kötöttebb irányba terelni a munkájukat (például gyakran jöttek oda hozzám, egyértelmü útmutatást kérve), vagy elhagyni a kötöttségek minél nagyobb részét (kísérletezést kezdeményeztek terv nélkül, túl sok szünetet tartottak, stb.). Ezen jelenség kezelése nem kis feladat volt, különösen azoknál a résztvevőknél, akiket korábban nem ismertem.

Érdemes megvizsgálni, hogy vannak-e a tapasztalatoknak életkori, vagy a megvalósulás kereteitől függő vonatkozásai. Az alábbi alfejezetekben igyekszem ezt az összehasonlítást elvégezni. Ennek sajnos problémája, hogy a megvalósulás keretei nem szétválaszthatóak az életkori sajátosságoktól, mivel egyetemisták csak tanórai keretben, középiskolások csak 4 órás külön alkalmakon vettek részt a módszeren.

\subsection{A kutatásmódszertan alkalmazásával kapcsolatos tapasztalatok}

Életkortól és keretektől függetlenül jól látszik, hogy a tudományos módszertanokkal nem foglalkoznak a középiskolai oktatásban, illetve ez nagy mértékben függ a tanár személyétől. Ez abból is látszik, hogy a középiskolások külön alkalmain látszott, hogy a tanáraik érdemben foglalkoznak ezekkel a kérdésekkel a tanóráikon, míg az egyetemisták - ott jobban szór a fizika oktatási háttere - esetében ez csak néhányakra volt jellemző.

Ennek ellenére vannak standard hibák, amelyeket egyöntetüen elkövetnek a csapatok. Ezek a hibák egyébként inkább hiányosságok, semmint elhibázott, de megtett lépések. Amit rendszeresen kihagynak a résztvevők:

- A feladat tisztázása után nem végeztetik el a kísérletet újra a vezetővel.

- Ide tartozik, hogy a legtöbben maguk sem végzik el, pedig abból sok minden kiderül, föleg a vezető által végrehajtott kísérlettel összehasonlítva.

- A kísérleteket/méréseket érdemes többször is elvégezni, ugyanazon paraméterek mellett is.

- A kísérlet végrehajtásában szereplő eszközöket érdemes „bemérni”, legalábbis a legegyszerübbeket (például a standard súlyok tömegét).

Mindezen hiányosságok ellenére az érdeklődés átsegítette a nehézségeken azokat a csapatokat, amelyek pozitív attitűddel álltak hozzá a feladathoz. Ők meglepően hamar képesek voltak a tanultakat kreatívan alkalmazni, gyakran megtalálva a keresett választ. 
Itt érdemes kiemelni egy fontos különbséget a két megvalósulási mód között. A külön alkalomra csak olyan diákok jöttek el, akik érdeklődnek a fizika iránt, és vagy ennek mentén, vagy a tanár által összeválogatott csapatban vettek részt. Így a motivációval csak kisebb gondok voltak. Az egyetemi tanórákon résztvevőknél sajnos nagyobb volt a szórás a motiváció tekintetében. Ugyanis az előzetes bejelentés ellenére többen is eljöttek azért, mert úgy gondolták, hogy „,kötelező”.

\subsection{Tervezés és dokumentálás}

Ezen a ponton látszott a legnagyobb tanácstalanság a résztvevőkön. Mint korábban írtam, a szabadságnak és kötöttségnek ezzel a kombinációjával nehezen tudtak mit kezdeni.

De ezen felül jellemző volt más is. Problémák akadtak a gondolatok linearizálásával, ami előfeltétele lenne az egymásra épülő kísérletek tervezésénél. Volt, aki egyszerre 3-5 különböző kísérletet akart elvégezni, de volt olyan csoport is, amelyik ad hoc szeretett volna próbálkozni.

Jellemző jelenség, hogy a hirtelen ötletektől vezérelve az éppen kísérletező csoport a leadotthoz képest még 1-2 kísérletet végrehajtott. Ez önmagában nem gond, de azért szembement a módszer logikájával.

Külön problémát jelentett, és néhány csoport munkáját egy időre vakvágányra is vitte, hogy a kísérletek eredményeit nem írták le megfelelően, vagyis a dokumentálás nem jól működött. Ezt a helyzetet súlyosbította, hogy a tervezés során is a lehető legminimálisabb munkát igyekeztek elvégezni. Egyes csoportokat többször is vissza kellett küldeni, hogy legalább a minimális információkat írják le, és ha lehet úgy, hogy én is el tudjam olvasni.

\subsection{Csoportmunka}

A közös tevékenység kapcsán az első kihívás a fegyelem megfelelő szintű fenntartása. Ugyanis a biztonság fenntartása okán mindenképpen fegyelmet kell tartani, ez azonban nem ronthatja a módszer játékosságát, a csoportok szabadságát. Jellemző kihívás volt a helyén kezelni az önmaguknak túl sok, vagy túl kevés szünetet adó csoportokat.

A fegyelem fenntartása a két különbözö keretrendszerben különböző kihívásokkal terhelt. A tanórán belül az ismerős környezet, a megszokott szereposztás és menetrendek adták a pedagógiai környezetet, a külön alkalmakon a kihívás éppen abban állt, hogy a résztvevők nem ismertek sem engem, sem a környezetet, és a megszokott tanár-diák szereposztásból kiindulva kellett az egyensúlyi helyzetet kialakítani és fenntartani.

Egy másik kihívásrendszer alapja az, hogy a résztvevők nagy általánosságban a kiscsoportos munka módszereiről sem tudással, sem tapasztalattal nem rendelkeznek. Nagyon látványos volt a különbség, ha a résztvevők között összejött egy-egy olyan csoport, amelynek volt tapasztalata a közös munkában, vagy akár nem tanórai közös tevékenységben együtt is munkálkodtak.

A csapatok összetétele a szokásos csoportdinamikai kérdéseken túl alapvetően meghatározta a kezdeményezőkészséget is, még azoknál a csapatoknál is, akiknek nem nagyon volt konkrét elképzelésük, mégis aktívak tudtak maradni.

Az egyik legkézzelfoghatóbb tapasztalat is a kezdeményezőkészséghez és motiváltsághoz kapcsolódik. A 4 órás időtartamban megtartott alkalmaknál jól látszott, hogy két óra aktív munka után még a legaktívabb csapatok is elfáradtak (a tanórai keretben ez a probléma nem merült fel, a módszer kitöltötte a rendelkezésre álló időkeretet, sőt, néha még kevésnek is bizonyult). Ez egyrészt a „közös agyalásnak" tudható be, másrészt - és ez még jellemzőbb - a keretek tiszteletben tartásával kezdtek gondjaik lenni. Volt olyan résztvevői kör, akik teljes körben közös gondolkodásba mentek át, de volt olyan is, amikor további kísérleti bemutatókkal és beszélgetéssel sikerült a maradék időt kitölteni. 
Ezen a helyzeten a feladat megváltoztatása sem segít. Próbáltam két alkalommal is egy második (vagy harmadik) feladatot kiadni, hátha a téma változása újra motiválja a résztvevőket, de sem a kezdeményezőkészség, sem a koncentráció nem tért vissza a korábbi szintre, így mindenképpen a kereteket kellett megbontani.

\section{4. Összefoglalás}

A fentiekben bemutatásra került egy élménypedagógiai módszer, amelynek lényege, hogy a résztvevők kiscsoportban, maguk által előre tervezett kísérletek segítségével keressenek választ valamilyen természettudományos, vagy technikai kérdésre. A módszer tapasztalatai is összefoglalásra kerültek, figyelembe véve, hogy azt vagy egyetemi tanórák keretében, vagy középiskolásoknak szervezett külön alkalmakon bonyolítottuk le.

A módszer a résztvevőknek mindenképpen újdonság, és saját bevallásuk szerint is sokat tanulnak belöle. Főként a már tudottan természettudományos, vagy müszaki pályára készülő diákok dicsérték a módszert, de a mérnök hallgatók visszajelzése is az volt, hogy „még több ilyet!”. Amennyiben a megfelelő játékosságot és szabadságot is sikerül biztosítani, az alkalmak kifejezetten jó hangulatban, aktív közös tevékenységgel telnek.

Külön kiemelendő a középiskolások esetében a fizika-tanáraik hozzáállása és oktatási tevékenysége. A módszer alkalmazása során kritikus fontosságú volt, hogy építhettem az általuk tanítottakra, illetve a tudományokkal kapcsolatos, és diákoknak átadott hozzáállásuk is nagy segítségemre volt.

A tapasztalatok megmutatták a módszer korlátait, és ezzel együtt a továbbfejlesztés irányait is.

A legnyilvánvalóbb fejlesztési irány az időkeret növelése az egyetemi tanóra kereteiben. A másik hasonló irány a módszer alkalmazásának rendszeressé tétele (ami viszont jelenleg nem realitás).

Külön kihívás a külön alkalmak tervezésénél, hogy azok a beszélgetések, kísérleti bemutatók, amik az aktív koncentrációt követő időtartamot kitöltik, szervesebben kapcsolódjanak a módszerhez magához. Vagy ezek helyett bevezethető más is.

Tartalmilag érdemes a feladat-repertoárt bővíteni, illetve érdekes kihívás egy-egy hallgató- vagy diákcsoporttal kitalálni új feladatokat. Ez utóbbi természetesen hosszabb távú, rendszeres találkozást, komolyabb előkészületeket igénylő folyamat lehet. Ennek az útnak a szélső pontja, ha az arra alkalmas diákok maguk adnak feladványt az oktatóknak...

Az új feladatok kidolgozása során fontos nézőpont, hogy a mérnök képzés tekintetében feladatokkal bővüljön a módszer, amelyek a résztvevők szakmájához, konkrét tervezési-fejlesztési tevékenységéhez jobban illeszkednek.

Összességében elmondható, hogy bár a módszer sok ponton kiforratlan, és továbbfejlesztésre szorul, a megvalósult alkalmak tapasztalatai és a visszajelzések alapján érdemes foglalkozni ezzel. A módszer szokatlansága miatt a résztvevők sokat tanulhatnak, épülhetnek egy-egy alkalomból, és a természet- és technikai tudományok iránt érdeklődőknek jó hangulatú időtöltésnek sem utolsó. Remélem, nemsokára újra lehetőségem lesz ilyen alkalmat vezetni.

\section{Köszönetnyilvánítás}

A cikkben ismertetett módszer szakmai anyagainak kidolgozása, és a középiskolások élménypedagógiai alkalmai, illetve azok tapasztalatainak összegzése az EFOP-3.4.4-16-2017-00008 „"Tudás - Vár a Miskolci Egyetem!" A felsőoktatásba való bekerülést elősegítő készségfejlesztő és kommunikációs programok megvalósítása, valamint az MTMI szakok népszerüsítése a felsőoktatásban” pályázat támogatásával valósult meg. 
Szeretnék köszönetet mondani Pántyáné Kuzder Máriának és Bagány Máténak, akik kiválogatták a leginkább érdeklődő és elhivatott tanítványaikat, és megszervezték az eljutásukat a külön alkalmakra. Külön köszönet nekik azért az elköteleződésért, amit a fizika, a müszaki tudományok, és azok oktatása iránt tanúsítanak, és amit nagy sikerrel adnak át diákjaiknak.

\section{Irodalom}

[1] Feynman, R. P., Leighton, R. B., Sands, M.: Mai Fizika 1. A modern természettudomány alapjai-A mechanika törvényei, Müszaki Könyvkiadó, Budapest (1970)

[2] Kata, J.: Mérnöki módszerek a pedagógiában, Typotex Kiadó, (2012), ISBN 978-963-279-774-8

[3] Majár, J.: A müszaki felsőoktatás új kihívásai a 21. században, MultiScience - XXX. microCAD International Multidisciplinary Scientific Conference University of Miskolc, Hungary, 21-22 April 2016, ISBN 978-963-358-113-1 https://doi.org/10.26649/musci.2016.053

[4] Radnóti, K., Nahalka, I., Poór, I., Wagner, É.: A fizikatanitás pedagógiája, Nemzeti Tankönyvkiadó, Budapest (2002)

[5] Majár, J.: Érdekes jelenségek vizsgálata kisérleteken keresztül - Egy élmény-pedagógiai módszer rövid leírása, tanulmány az EFOP-3.4.4-16-2017-00008 „"Tudás - Vár a Miskolci Egyetem!" A felsőoktatásba való bekerülést elősegítő készségfejlesztő és kommunikációs programok megvalósítása, valamint az MTMI szakok népszerüsítése a felsőoktatásban” pályázat keretében (2018)

[6] Majár, J.: A Miskolci Egyetem Fizikai Intézetének laboratóriumai: kihivások és lehetséges válaszok, MultiScience - XXVIII. microCAD International Multidisciplinary Scientific Conference University of Miskolc, Hungary, 10-11 April 2014, ISBN 978-963-358-051-6

[7] Majár, J.: Érdekes jelenségek vizsgálata kísérleteken keresztül II. - Egy élmény-pedagógiai módszer első tapasztalatai, tanulmány az EFOP-3.4.4-16-2017-00008 ,"Tudás - Vár a Miskolci Egyetem!" A felsőoktatásba való bekerülést elősegítő készségfejlesztő és kommunikációs programok megvalósítása, valamint az MTMI szakok népszerüsítése a felsőoktatásban” pályázat keretében (2019)

[8] Budó, Á.: Kisérleti Fizika I., Tankönyvkiadó, Budapest 1970

[9] Budó, Á.: Kísérleti Fizika II., Tankönyvkiadó, Budapest 1972

[10] https://en.wikipedia.org/wiki/Reverse_engineering 